\title{
MARKETING COMMUNICATION ADAPTATION OF MSME IN THE DIGITAL ERA: RESPONDING TO CHANGES IN CONSUMER BEHAVIOR
}

\author{
Nina Septina, Lilian Danil, Ria Satyarini \\ Fakultas Ekonomi Universitas Katolik Parahyangan
}

\begin{abstract}
Technological development is one of the important factors in the process of purchasing decisions that affect consumer spending patterns. These changes are not just happening in Indonesia but are applied globally. The availability of high-speed internet connections, as well as the consumer's acceptance of the power of social media and the number of online offerings which become increasingly attractive, support the growth of online business. This research aims to study the consumer behavior changes in the digital age. Data collection is done with a qualitative approach in the form of focus group discussion and in-depth interviews in several cities in Indonesia. Research results are applied as the basis for consideration for Small Medium Enterprises in conducting its marketing strategies adaptation in order to be sustainable in the digital age.
\end{abstract}

Keywords: consumer behaviour, consumer spending patterns, small medium enterprises

\section{INTRODUCTION}

\subsection{Background}

The rapid development of technology makes business people strive to find the best opportunities in the midst of changing times. Internet usage in Indonesia has reached 51 percent and the penetration of active social media usage has reached 40 percent, as can be seen in Figure 1. Furthermore, internet users in Indonesia in 2018 to 2022 are predicted to still experience an increase, as depicted in Figure 2.

\footnotetext{
*Corresponding Author.

e-mail: septina@unpar.ac.id
} 
Review of Management and Entrepreneurship

Volume 03, Number 02, October 2019

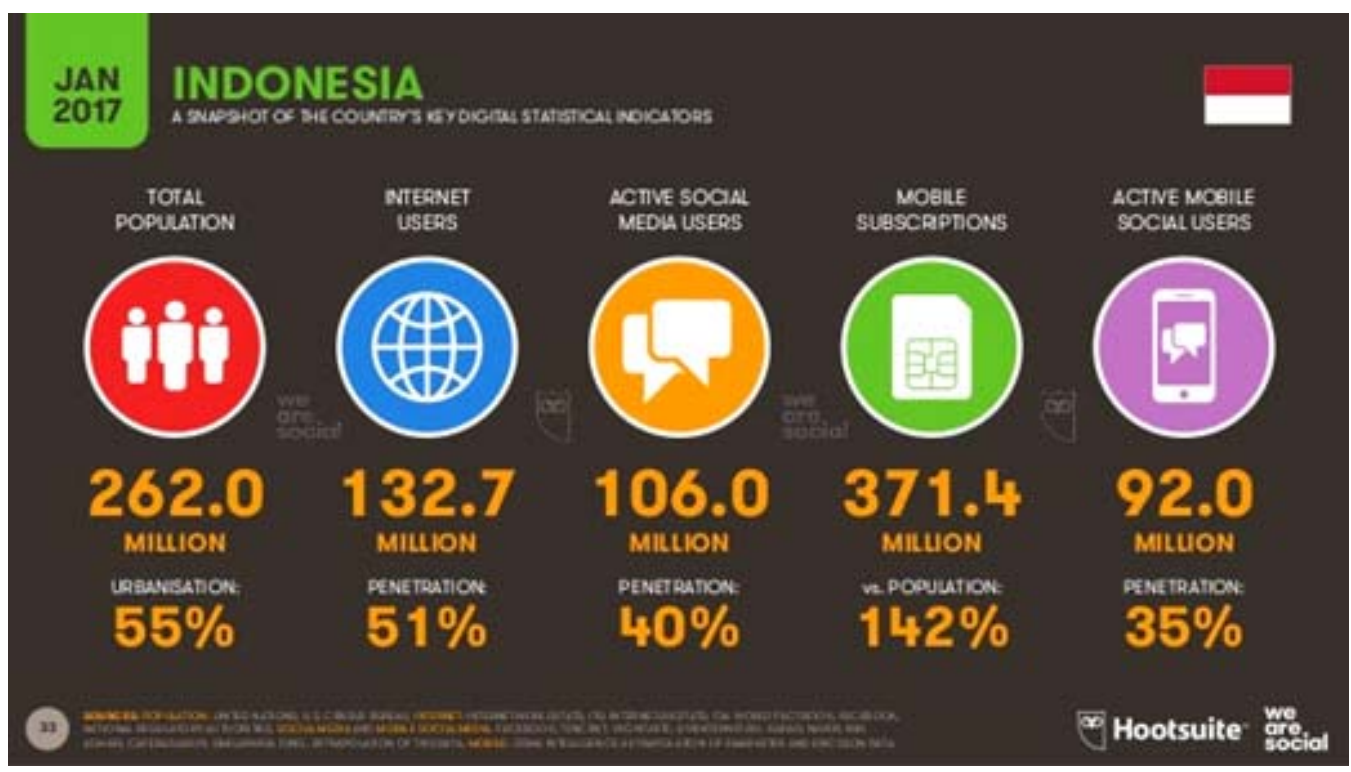

Figure 1 Social Media Use in Indonesia

Source: www.wearesocial.com, 2017

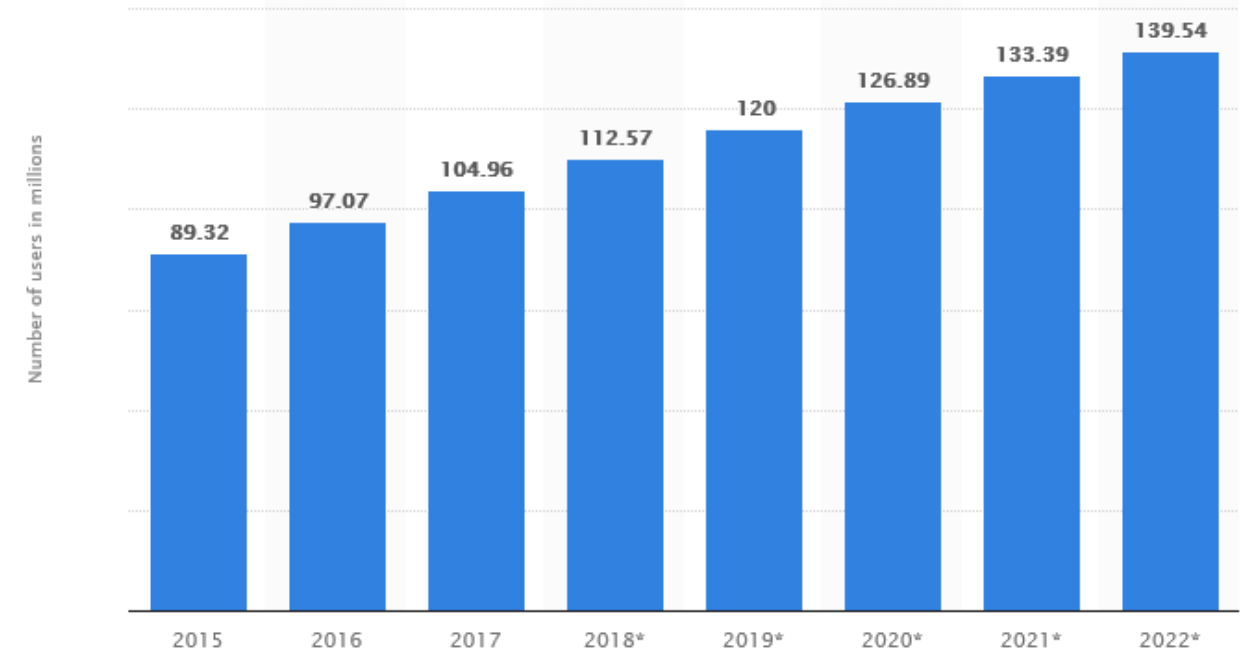

Figure 2 Internet Users in Indonesia (in millions)

Source: www.statista.com, 2017 
The availability of high-speed internet connections, as well as consumer acceptance of social media presence and the number of increasingly attractive online offers, strongly supports the growth of online businesses. Consumers are now deeply involved with the use of digital media in everyday communication as a potential market that is very interesting to utilized by MSMEs, especially on social media and the digital marketplace as an alternative channel of communication to deliver promotional products.

In Figure 3, it appears that in the digital age, there is an increasing use of social media. These media, such as Facebook, Instagram, Twitter, Google+, and Path are the five most used social media by consumers in Indonesia. The use of social media not only serves to establish communication between certain individuals or communities, but also has been utilized for commercial purposes such as online marketing activities. Even the results of the Special Creative Economy Survey (Bekraf, 2016) showed that 53.72 percent of MSME actors had used social media as a promotional media.

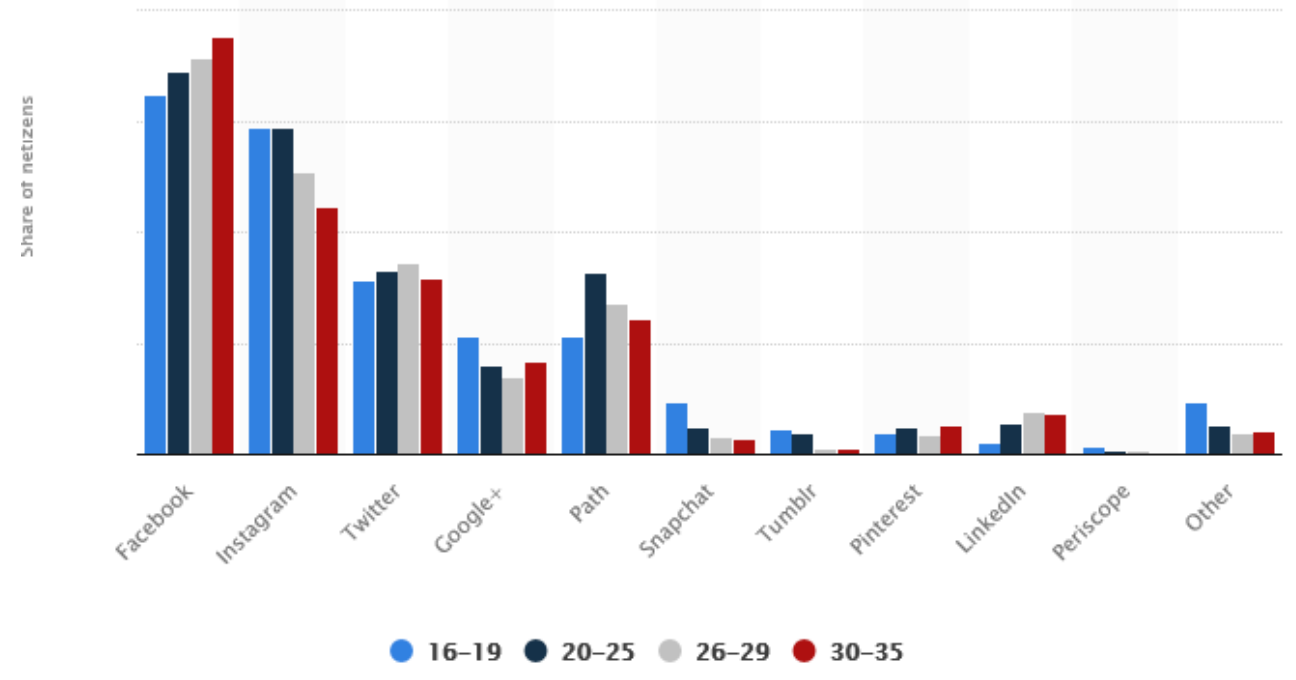

Figure 3 Social Media User in Several Consumer Age Sub-Groups in Indonesia Source: www.statista.com, 2017 
The use of online marketplace sites in Indonesia is increasingly widespread. Until now, widely used marketplace sites include Blibli, Tokopedia, Bukalapak, Lazada, Elevania, and Shopee. It can be seen in Figure 4 that Lazada and Blibli are the two largest and relatively stable market shareholders.

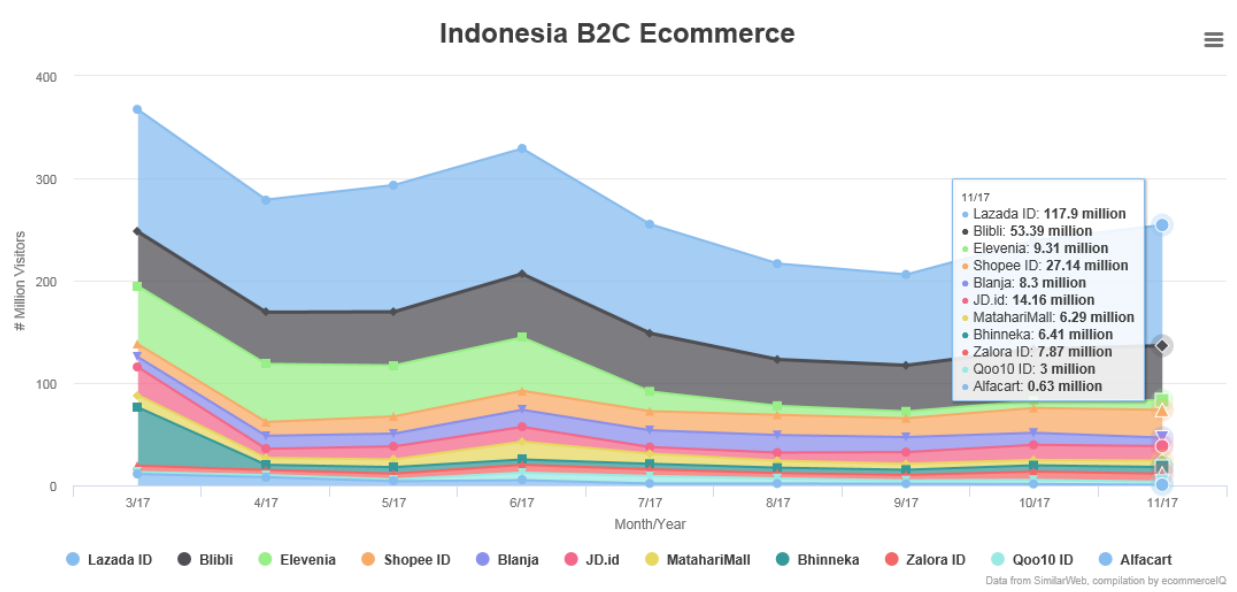

Figure 4

Source: https://ecommerceiq.asia/top-ecommerce-sites-indonesia/

\section{PROBLEM DEFINITION}

The rise of the development of the use of online platforms does not necessarily remove the existence of offline businesses. Some MSMEs in Indonesia have also begun to use online platforms for commercial purposes. The MSMEs who are interested in taking advantage of this opportunity certainly need to prepare themselves with more mature business decisions and strategies. In this situation, competition becomes increasingly fierce and requires more creative marketing communication space for MSMEs to offer their products.

Based on this situation, the question arises "Do changes in consumer behavior in the digital era occur in all products or only in a specific group of products?" The findings of this course are needed to support the sustainability of MSME sales performance. Thus, studies that examine changes in consumer behavior in purchasing decisions on various product groups become important, so MSME's decision in adapting online platforms does not become a baseless decision. 


\subsection{Goals and Benefits}

The purpose of this study is to determine consumer opinion on online platforms, and study consumer attitudes towards online platforms and find out the types of products for which purchasing decisions have switched to online platforms. The results of the study are useful to be used as a foundation in designing marketing strategies that will be recommended to MSMEs.

\section{THEORETICAL REVIEW}

Several previous studies have only focused on psychotropic relationships with generic product shopping (Brown et al 2003, Wadesarathy, 2003), both psycho-graphic and demographic factors with generic shopping on the internet (Girard et al., 2003), and some psychological behaviors that influence clothing purchases online (Goldsmith and Flynn 2004).

Other researches show how previous online shopping experiences affect future intentions to shop (Goldsmith 2002; Jayawardhena et al 2007; Seock 2003). In addition, other researches show the effect of gender on online shopping intentions and behavior (Brown et al., 2003; Jayawardhena et al 2007; Vijayasarathy 2003). In making the purchase process, consumers generally go through 5 (five) sequential stages (Figure 5). This depends on the level of consumer involvement in the buying process. Here is a simple model of consumer decision making (Kotler and Keller, 2012: 188);

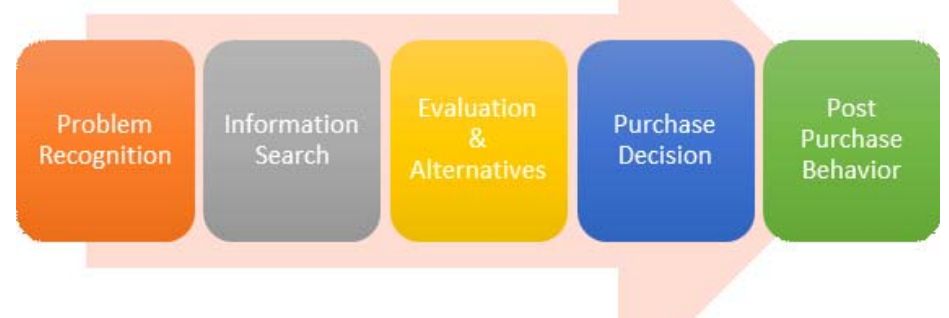

Figure 5 Purchasing Decision-making Process

Source: Kotler and Keller, 2012:188, 2017 


\subsection{Problem Recognition}

The buying process begins with an introduction to a problem or need. Needs can arise when consumers feel the existence of external or internal stimuli that encourage themselves to recognize needs.

Internal stimuli arise from within humans themselves, while external impulses come from outside the human self or the environment. Needs have a certain level of intensity. The greater the level of intensity, the stronger the drive that arise to reduce it by looking for new objects that can satisfy their needs.

\subsection{Information Search}

Consumers who feel the stimulation of their needs will then try to find more information involved in the search for needs. Information retrieval is a motivated activity of knowledge stored in memory and the acquisition of information from the environment. Consumer information can come from the following sources:

a) Personal resources: family, friends, neighbors or acquaintances.

b) Commercial sources: advertising, salespeople, intermediary traders.

c) General sources: mass media.

d) Sources of experience: handling product problems, product inspection, and product usage.

The effect of these sources of information varies depending on the type of product and the characteristics of the consumer. In general, consumers get most of the information about a product from commercial sources, which are sources dominated by marketers. However, the most effective information comes from personal sources. Each information performs a different function in influencing purchase decisions. Commercial information usually performs the function of providing information and private sources carry out the legitimacy and / or evaluation functions.

\subsection{Evaluation of Alternatives}

After receiving a lot of information, consumers learn and process the information to make a final choice. There are many consumer assessments processes for products. Evaluation of product alternatives is a process in which 
an alternative choice is adjusted and chosen to meet the needs of consumers. The basic concepts in the process of evaluating alternatives are:

a) Consumers try to make ends meet

b) Consumers look for certain benefits from product usability

c) Consumers view each product as a collection of attributes with different abilities in providing the benefits sought to satisfy needs.

d) Consumers have different properties in looking at the attributes that are considered relevant and important. Consumers will pay great attention to the attributes that provide the benefits they seek.

\subsection{Purchase Decision}

After the previous steps, the consumer must make a decision whether to purchase or not. Consumers might form an intention to purchase and tend to purchase the brand they like. However, there are other factors that determine the purchasing decision, namely the attitudes of others and unexpected situational factors.

a. Other people's attitude

The extent to which other people's attitudes can reduce the product alternatives that someone likes will depend on two things. First, the intensity of other people's negative attitudes towards consumer choices for the product. Second, the motivation of consumers to obey the wishes of others. The closer the other person is to the consumer; the more consumers will change their purchase intentions.

b. Unforeseen situational factors

Consumers form an intention to purchase based on factors such as family income, price, and expected benefits of a product. Consumer decisions to modify, delay, or avoid purchasing decisions are strongly influenced by the risks he thinks about. For example, the amount of money to be spent, the uncertainty of attributes, and the amount of confidence.

If the consumer decides to buy, then the consumer will find a decision that must be taken regarding the type of product, brand, seller, quantity, service time, and method of payment. The decision-making process does not always follow the 
sequence above, and not all products require the decision-making process. For example, daily necessities such as food do not need any planning and consideration for purchasing.

\subsection{Post Purchase Behaviour}

After buying a product, consumers will experience satisfaction or dissatisfaction. The job of the marketer does not end only when the product is purchased; but continues into the post-purchase period.

a. Post-purchase satisfaction

Consumer satisfaction is a function of how close the expectations of consumers to the expected performance which consumers have. If product performance is lower than expectations, consumers will be disappointed. Conversely, if product performance is higher than expected, then consumers will be satisfied. These feelings will decide whether the consumer will do a repeat purchase of the brand bought and decide to become a consumer of that brand and to refer the brand to someone else.

b. Post-purchase action

Satisfaction and dissatisfaction with the product will affect subsequent consumer behavior. If the consumer is satisfied, then he will show a higher chance to do a repeat purchase of the product. Conversely, if a consumer is dissatisfied, he may not do so.

c. Post Purchase Use and Disposal

In addition to post-purchase behavior and post-purchase actions, marketers are also eager to monitor how consumers use and dispose of the products. This is done so that things do not happen that can harm the consumer and the environment due to the wrong, excessive, or less responsible use.

\section{RESEARCH METHODOLOGY}

The data collection was carried out qualitatively, namely through 2 focus group discussion (FGD) sessions and in-depth interviews, from October 2017 to September 2018. FGD participants for session 1 were 7 people, while session 2 amounted to 8 people. Both of these FGD sessions were held in the city of 
Bandung. The total number of respondents in the in-depth interview totalled 53 people, consisting of 9 people in Bandung, 10 people in Jakarta, 12 people in Surabaya, 6 people in Bali, 7 people in Bengkulu, and 9 people in Semarang. The sample criteria are consumers aged at least 17 years old, who has experienced online shopping at least once in the last 3 months.

\section{RESULTS AND DISCUSSION}

The first FGD session was attended by three students and four female students. Initially all used online platform because they wanted to try. However, two students decided not to use the online platform as a first choice in shopping, because they doubted the safety factor during the transaction. Two female students also stated that they would only shop online for unique, rare, collectible items, and items not available in stores in the city of Bandung, because they enjoyed the sensation of shopping offline. Two students and all students said they were always looking for information online about prices, promotions, and product availability. Online platforms are considered better than offline stores in terms of practicality of shopping because they do not need to bother with traffic jams and parking difficulties. In addition, it also offers more diverse choices than in an offline store. However there are weaknesses related to safety factors as evidenced by the fact that there are still people who cheat in transactions. In addition, on the online platform, personal feel has not been replaced by the role of customer-contact service. The online platform will only be used for products that have guaranteed quality, clear standard sizes, and realistic and affordable prices. Only one female student has switched to an online platform to shop for casual clothes and shoes. The rest use this platform as a complement to the main choice of offline stores.

The second session of the FGD was attended by four housewives and four male employees. Initially all used the online platform because they were curious to try. However, one employee decided not to use the online platform as a first choice in shopping, due to safety reasons during transactions where his coworkers had been tricked into making transactions. All participants stated that they were always looking for information online about price comparisons between several seller accounts, waiting for flash sales, and product explanations. 
Online platforms are considered better than offline stores in terms of practicality of shopping because they do not have to leave the house and do not need to bother with carrying the purchased product. In addition, it also offers more diverse choices than in an offline store. The weaknesses related to security factors are evident from the still often-heard-of fraud in the transaction. In addition, the customer service response online platform has not been well managed. All participants agreed that the online platform would only be used for branded products whose quality was guaranteed, if there were endorsers used, and if the seller have a large number of followers. Only two housewives have switched to online platforms to shop for mobile accessories, Muslim clothing, and cosmetics. The rest use this platform as a complement to offline stores.

In-depth interview in the city of Bandung consists of 9 people, 5 female lecturers and 4 bank employees (male). All interviewees initially used the online platform because they followed the advice from the social environment, both colleagues and family. Two lecturers and one bank employee decided not to use the online platform as the first choice in shopping, because they felt the atmosphere of offline shopping could not be replaced by an online platform. Two bank employees said they would only shop online for products that were not available in Bandung stores. All interviewees stated that they were always looking for information online about product prices, product substitutions, and promotional information. Online platforms are considered better than offline stores in terms of practicality of shopping because they do not need to leave the house and have a variety of choices. Regarding weaknesses, sometimes there are mistakes in product delivery that is not in accordance to what consumers ordered. In addition, there is no service on the online platform that replaces the role of customer service in offline stores. The online platform will only be used for seller accounts that are clearly standardized in size and for products that are not easily broken. Only one lecturer has switched to an online platform to shop for clothes and accessories for families, as well as ordering items online, go-food, and taxi services. The rest use this platform as a complement to offline stores.

The in-depth interview in Jakarta was attended by 2 male lecturers, 2 housewives, and 6 female students. All use online platforms because at first, they just wanted to try. Furthermore, one lecturer, two housewives, and two students decided not to use the online platform as the first choice in shopping, because 
they still doubted the safety factor during the transaction, and they enjoyed the sensation of shopping offline. However, all interviewees stated that they were always looking for information online about product explanations and promotions that still apply. Online platforms are considered better than offline stores in terms of practicality of shopping because they do not need to bother with traffic jams and parking difficulties. In addition, it also offers more diverse choices than in an offline store. Existing weaknesses are related to safety factors as evidenced by the fact that there are still people who cheat in transactions. In addition, on the online platform the role of contact person is not optimal in providing a positive response. The online platform will only be used for products that have guaranteed quality, clear standard sizes, and realistic and affordable prices. One lecturer, one housewife and two female students who have switched to online platforms, in terms of using online transportation services and ordering food through go-food. The rest use this platform as a complement to offline stores.

In-depth interview in the city of Surabaya consists of 12 interviewees, 3 female lecturers, 2 male lecturers, and 4 female students, and 2 education staff. Student interviewees initially used an online platform because they were influenced by peer groups. Other interviewees were initially influenced by colleagues and family. Two female lecturers and one education staff decided they would not use the online platform as the first choice in shopping, because the online shopping experience was not as pleasant as being in the store. Two male lecturers said they would only shop online for electronic products that clearly have guaranteed quality. All interviewees stated that they were always looking for information online about product information and price comparisons. Online platforms are considered better than offline stores because consumers do not need to leave the house and there is often a flash sale. The disadvantage is that sometimes there are delays in the delivery of products ordered by consumers. Another weakness is that there is no service standard on the online platform that replaces the role of customer service in offline stores. All interviewees stated that the online platform will only be used for products that are not perishable. Only one female lecturer and one female student have switched to an online platform to shop for clothes, cosmetics, and use go-food. The rest keeps using the offline platform as the main choice in shopping. 
In-depth interview in Bali consists of 6 interviewees, all male, 4 hotel employees and two online taxi drivers. All hotel employee interviewees initially used the online platform because they were influenced by peer groups, while taxi drivers were affected by families. One employee and two drivers decided not to use the online platform as a first choice in shopping because the online shopping experience is not as pleasant. However, all interviewees stated that they were always looking for information online about product explanation information and price comparisons. Online platforms are considered better than offline stores because consumers don't need to leave the house. The disadvantage is because there are no store employees who assist in the purchase process. All interviewees stated that the online platform will only be used for products that are not perishable and are not available in offline stores. There hasn't been an interviewee who has switched to an online platform to shop, because they still use the offline platform as the main choice in shopping because shopping is a part of recreation with those closest to them.

Depth interview in the city of Bengkulu consists of 7 interviewees, two housewives, two male lecturers, and 3 female students. All interviewees initially used online platforms because they were influenced by their family. All interviewees stated that they were always looking for information online about product explanation, product information, and price comparison. Online platforms are considered better than offline stores because consumers do not need to leave the house. The disadvantage is that there are no store employees who assist in the purchase process and thus are less trusted because there are relatives who have been victims of fraud on this platform. No interviewee has switched to an online platform to shop because they will still use the offline platform as the main choice in shopping because it is a routine activity with the family on weekends.

In-depth interviews in the city of Semarang consists of 9 interviewees, two female employees of a gift shop, two male employees of a hotel, and five housewives. All interviewees initially used the online platform because they were influenced by peer groups. In addition, all interviewees stated that they always sought information online about product explanations and price comparisons. The online platform is considered better than the offline store because consumers do not need to leave the house, but the drawback is that they have to wait for the product to be sent within the next few days. All interviewees stated that the 
online platform will only be used for products that are not perishable. Not one interviewee has really switched to an online platform to shop, because they continue to use the offline platform as their main choice in shopping. They use go-food services all the time because they enjoy eating out more together. Three housewives and one hotel employee occasionally shop online for clothes, bags or shoes for gifts.

Based on this, it can be concluded that although the use of the internet has increased, but it only reached the stage of information retrieval. With all the advantages offered and limited services, online shopping has been accepted as an alternative, but has not yet been fully utilized as the main method of purchasing. If you pay attention to the opinions of consumers from various cities, a pattern can be seen that is causing the slow transition from offline shopping to online platforms, which is due to the high demand of consumers in enjoying the shopping atmosphere as part of socialization activities with their immediate environment. What has begun to shift is for branded products, clothing, cosmetics, collectible items, mobile accessories, online taxi services and food ordering services.

\section{CLOSING}

MSMEs must realize that technological development is not something that must be resisted, so that they are not left behind and can continue to be sustainable. However, it does not mean that all changes must be immediately followed. Based on the findings of this study, it appears that consumers have not been one hundred percent switched to online platforms. The crucial point is in the process of finding information before deciding what products to buy and where. Thus, they need to prepare search engine optimization so the browsing process directs consumers to the MSMEs concerned, and also need to prepare marketing communication design content in digital media that can provide information as clearly as possible with a communicative display.

In addition, MSMEs are not advised to switch from the offline platform to online, because there are still more consumers choosing to shop offline. However, if the resources are sufficient, MSMEs can utilize the online platform as an additional service that will optimize their business performance. 


\section{REFERENCES}

Brown, M., N. Pope, and K. Voges. 2003. Buying or Browsing? An Exploration of Shopping Intentions and Online Purchase Intention. European Journal of Marketing 37: 1666-1684.

Data Statistik dan Hasil Survei Ekonomi Kreatif, Kerjasama Badan Ekonomi Kreatif dan Badan Pusat Statistik, 2016 https://www.bekraf.go.id/pustaka/page/datastatistik-dan-hasil-survei-khusus-ekonomi-kreatif (akses 29 Juli 2017, 10.09).

Digital in 2017: Southeast Asia, www.wearesocial.com, https://wearesocial.com/ special-reports/digital-southeast-asia-2017 (akses 15 Juli 2017, 13.26).

Girard, T., P. Korgaonkar, and R. Silverblatt. 2003. Relationship of Type of Product, Shopping Orientations, and Demographics with Preference for Shopping on the Internet. Journal of Business and Psychology 18: 101-120.

Goldsmith, R.E. and L.R. Flynn. 2004. Psychological and Behavioral Drivers of Online Clothing Purchase. Journal of Fashion Marketing and Management 8: $84-95$.

Jayawardhena, C., L.T. Wright, and C. Dennis. 2007. Consumers Online: Intentions, Orientations and Segmentation. International Journal of Retail \& Distribution Management 35: 515-526.

Kotler, P. \& K.L., Keller. 2012. Marketing Management. New Jersey: Pearson Prentice Hall, Inc.

Number of internet users in Indonesia from 2015 to 2022 (in millions) https:// www.statista.com/statistics/254456/number-of-internet-users-in-indonesia/ (akses 20 November 2017, 14.01).

Seock, Y.K. 2003. Analysis of Clothing Website for Young Customer Retention Based on a Model of Customer Relationship Management Via the Internet. Unpublished Dissertation. Faculty of the Virginia Polytechnic Institute and State University.

The Country's Top Ecommerce Websites, https://ecommerceiq.asia/top-ecommercesites-indonesia/ (akses 14 Desember 2017, 11.05).

Vijayasarathy, L.R. 2003. Shopping Orientations, Product Types and Internet Shopping Intentions. Electronic Markets, 13: 67-79.

Wade, J. 8 Nov. 2017. Instagram Statistics, https://www.smartinsights.com/socialmedia-marketing/instagram-marketing/instagram-statistics/ (akses 20 November 2017, 11.42). 